\title{
Interactions of planktonic algae and bacteria: effects on algal growth and organic matter dynamics
}

\author{
Hans-Peter Grossart ${ }^{1,2, *}$, Meinhard Simon ${ }^{1}$ \\ ${ }^{1}$ Institute for Chemistry and Biology of the Marine Environment, University of Oldenburg, PO Box 2503, \\ 26111 Oldenburg, Germany \\ ${ }^{2}$ Present address: Department of Limnology of Stratified Lakes, Institute of Freshwater Ecology and Inland Fisheries, \\ Alte Fischerhuette 2, 16775 Neuglobsow, Germany
}

\begin{abstract}
Interactions between phytoplankton and heterotrophic bacteria have been intensively studied, but many aspects of these interactions are still unknown because most of the studies were performed under non-axenic conditions. Therefore, we investigated the growth and release of dissolved organic matter of the marine diatom Thalassiosira rotula in axenic culture in comparison to T. rotula cultures inoculated with either a natural marine bacterial community (German Wadden Sea) or 3 different bacterial isolates. The isolates affiliated to the Roseobacter group (HP50), Hyphomonas (HP48) and Flexibacteriaceae (HP49) and were previously obtained from a T. rotula culture inoculated with a natural marine bacterial community (German Wadden Sea). To test whether the availability of inorganic nutrients, vitamins and trace metals affects algal growth, organic matter release and interactions with heterotrophic bacteria, we performed experiments with either Guillard's $f / 2$ or f/10 medium, which differ in their inorganic nutrient, vitamin and trace metal concentration by a factor of 5 . The bacterial community promoted growth of $T$. rotula in both media, as shown by the higher algal numbers relative to the axenic cultures, but also led to a rapid decline after the growth phase. Isolate HP50 promoted algal growth in the $f / 2$ medium, but inhibited growth in the f/10 medium, whereas isolate HP48 showed the opposite patterns. Isolate HP49 prevented algal growth in both media. T. rotula exhibited distinct release patterns of dissolved organic carbon (DOC), dissolved amino acids, dissolved neutral carbohydrates, transparent exopolymer particles (TEP) and protein-containing particles (Coumassie Blue-stainable particles, CSP), which were modulated by the bacteria added. TEP and CSP were produced by the growing alga only in the presence of bacteria, indicating that the bacterial modification of algal exudates and/or the bacterial decomposition of the alga are prerequisites for formation of these microparticles. Our results show that the presence of the bacterial community and of specific populations have distinct effects on the growth and organic matter release of $T$. rotula and presumably also on other algae.
\end{abstract}

KEY WORDS: Marine diatoms · Bacteria · DOC · Amino acids · Carbohydrates · TEP · CSP · Organic matter cycling

\section{INTRODUCTION}

Algal-bacterial interactions have received increasing attention in the recent past (Ferrier et al. 2002, Schäfer et al. 2002, Green et al. 2004, Pinhassi et al. 2004, Grossart et al. 2005, 2006a,b, Rooney-Varga et al. 2005). These interactions comprise the following 4 major modes: (1) bacteria and algae form symbioses, in which bacteria benefit from phytoplankton exudates, and algal growth is favoured by bacterial products such as re-mineralised nutrients, vitamins and other growth factors; (2) bacteria act as parasites on phytoplankton and, thus, can lead to lysis and death of their hosts, while algae can also inhibit bacterial growth by releasing antibiotic compounds; (3) commensalistic bacteria have no actual negative effect on phytoplankton, but the transition between commensalism and parasitism is highly variable in time; and (4) bacteria 
are only loosely associated with phytoplankton and, thus, can efficiently compete for limiting nutrients such as phosphate. For more details of these interactions see Grossart (1999) and references therein. These interactions have often been neglected, but may be as important as inorganic nutrient supply, grazing and viral lysis in controlling the development of diatom blooms.

It has been shown that the same bacteria can either stimulate or even inhibit algal growth, depending on the physiological status of the algae (Grossart 1999). Further, algal exudation affects the presence and activity of distinct bacterial communities, which, in turn, control the amount and composition of the dissolved organic matter (DOM) released (Grossart et al. 2005, 2006a).

The composition of exuded organic matter is often characteristic of the algae releasing it (Myklestad 1974, 1995). Skeletonema costatum, for example, releases large amounts of DOM rich in carbohydrates, while Emiliania huxleyi exudes small quantities of DOM with lower proportions of carbohydrates (Biersmith \& Benner 1998). There are many reports on massive production of extracellular polymers in various aquatic environments, especially in times of nutrient depletion, as the synthesis and exudation of polymers often increase under these conditions (e.g. Obernosterer \& Herndl 1995, Biddanda \& Benner 1997, Søndergaard et al. 2000). Roughly $10 \%$ of the photosynthetically fixed carbon is released by phytoplankton (Baines \& Pace 1991, Carlson et al. 1998), but this fraction is highly variable in the field, ranging between 1 and $70 \%$ (Baines \& Pace 1991). The high variability points to great fluctuations in algal DOM release and also in bacterial DOM consumption. Today, we still lack a detailed understanding of the bacterial decomposition of specific phytoplankton-derived DOM compounds and how changes in algal-bacterial interactions affect the amount and quality of DOM in aquatic systems.

The role of heterotrophic bacteria in algal-bacterial interactions seems to be ambiguous. The presence of bacteria affects the net-release of DOM and the formation of transparent exopolymer particles (TEP), proteinaceous Coomassie Blue-stainable particles (CSP) and aggregates (Grossart et al. 2006a). TEP have been identified as an important agent for aggregation (Passow 2002a), and various studies have shown that TEP is produced by phytoplankton, but also by bacteria and from dissolved precursor material (Zhou et al. 1998, Passow 2002b, Engel et al. 2004). These processes greatly depend on the physiological state of the algae (Grossart et al. 2006a,b), and there are distinct differences in the quality of the organic matter released by different diatoms, its bacterial consumption and growth. Algal-bacterial interactions can also increase phytoplankton aggregation and sedimentation by modifying phytoplankton-derived DOM and POM, but, on the other hand, may reduce sedimentation of algal-derived organic matter due to bacterial decomposition (Grossart et al. 2006a).

We hypothesise that algal growth and release of organic matter greatly depend on the presence of distinct bacterial communities and that algal-bacterial interactions vary with changing concentrations of inorganic nutrients, vitamins and trace metals. Therefore, we studied whether changes in algal-bacterial interactions result in (1) changing concentrations of DOM, TEP and CSP, (2) variable decomposition patterns of phytoplankton-derived organic material by specific bacteria, and (3) differences in algal nutrition and growth, as well as organic matter dynamics. We measured algal growth, release of DOM and concentrations of TEP and CSP in axenic cultures of Thalassiosira rotula incubated in $f / 2$ or $f / 10$ medium and compared these values with those from the same cultures that were either incubated with a natural community of marine bacteria or with single isolates. Our results show that phytoplankton growth, dynamics of DOM release and numbers of TEP, as well as CSP vary with the bacteria added and/or algal nutrition.

\section{MATERIALS AND METHODS}

Experimental design and sampling. An axenic culture of Thalassiosira rotula (CCMP 1647) was obtained from the Provasoli-Guillard National Center for Culture of Marine Phytoplankton (CCMP, Maine, USA). The alga was tested for axenic conditions by (1) epifluorescence microscopy, (2) cultivation on agar plates, and (3) PCR-based methods (Grossart et al. 2005). The alga was incubated in batch cultures in Guillard's $f / 2$ or $f / 10$ medium to generate different availabilities of inorganic nutrients. To test for the effect of specific algal-bacterial interactions, the diatom culture (ca. $1 \times 10^{3}$ cells ml $^{-1}$ ) was either inoculated with $10 \mathrm{ml}$ of seawater (containing the natural bacterial community, ca. $1 \times 10^{6}$ cells $\mathrm{ml}^{-1}$ ) or with $10 \mathrm{ml}$ of bacterial isolates (ca. $1 \times 10^{6} \mathrm{cells} \mathrm{ml}^{-1}$ ) previously isolated from the same diatom culture (see next paragraph). All cultures were run in triplicate in $1.2 \mathrm{l}$ rolling tanks $(5 \mathrm{rpm})$ at $15^{\circ} \mathrm{C}$ and in a $12 \mathrm{~h}$ light:12 h dark cycle for $30 \mathrm{~d}$.

The seawater used for inoculation was collected in June 2000 from the German Wadden Sea $\left(53^{\circ} 42^{\prime} \mathrm{N}\right.$, $\left.7^{\circ} 50^{\prime} \mathrm{E}\right)$ and filtered through $5.0 \mu \mathrm{m}$ Nuclepore membranes to reduce contamination by the natural algal community and protozoan growth. The bacterial strains (HP48, HP49 and HP50) were isolated from Thalassiosira rotula and grown on MB agar plates 
(Difco). Before inoculation all bacterial strains were rinsed 3 times in sterile seawater and diluted to ca. $1 \times$ $10^{6}$ cells ml ${ }^{-1}$. HP48 is closely related to the alphaproteobacterium HP40 of the Hyphomonas group, HP49 to the Sphingobacterium HP34 (Flexibacter aggregans) (Grossart et al. 2004) and HP50 to the alphaproteobacterium HP44w of the Roseobacter group. All isolates were sequenced as described in Grossart et al. (2004) and have been deposited in GenBank under the Accession Numbers DQ148413 (HP48), DQ150528 (HP49) and AY841778 (HP50).

Samples for all measured parameters were collected periodically under sterile conditions (clean bench) and immediately processed for further analyses. The water withdrawn was replaced by sterile seawater to avoid air bubbles inside the rolling tanks.

Algal and bacterial abundance. Free-living and attached bacteria from 1 to $5 \mathrm{ml}$ sub-samples were counted on 0.2 and $5.0 \mu \mathrm{m}$ Nuclepore membranes, respectively, after staining with DAPI (4'6'diamidino2-phenolindole) by epifluorescence microscopy (Axioplan) at $1000 \times$ magnification (Porter \& Feig 1980). Bacteria retained on the $5.0 \mu \mathrm{m}$ membranes were considered attached to either algal cells or organic particles, which formed during incubation. We are aware of the fact that bacterial colonies and cells $>5 \mu \mathrm{m}$ may have also been retained on the filters; however, microscopy revealed that this was seldom the case. The algae were counted by simultaneously using light and epifluorescence microscopy at $400 \times$ and $1000 \times$ magnification. A minimum of 10 replicates was counted for each bacterial and algal sample. Algal cells without any visible chlorophyll $a$ autofluorescence were defined as dead algal cells.

Dissolved organic carbon (DOC). Samples $(10 \mathrm{ml})$ were collected in glass ampoules after filtration through $0.2 \mu \mathrm{m}$ polycarbonate membranes (Nuclepore). Samples were acidified with $100 \mu \mathrm{l}$ of $85 \% \mathrm{H}_{3} \mathrm{PO}_{4}$, flame sealed and stored until analysis at $4^{\circ} \mathrm{C}$ in the dark. DOC was analysed by high-temperature combustion (Shimadzu TOC-5000) as described in Grossart et al. (2006a).

Amino acids. Samples $(10 \mathrm{ml})$ were filtered through $0.22 \mu \mathrm{m}$ pore size low-protein-binding filters (Acrodisc, Pall Corporation) and stored frozen at $-20^{\circ} \mathrm{C}$ until analysis. Concentrations of dissolved free amino acids (DFAA) were analysed by HPLC after ortho-phthaldialdehyde derivatisation according to Lindroth \& Mopper (1979) using 2 injections per sample. Dissolved combined amino acids (DCAA) were hydrolysed with $6 \mathrm{~N} \mathrm{HCl}$ at $155^{\circ} \mathrm{C}$ for $1 \mathrm{~h}$ and analysed as DFAA.

Neutral carbohydrates. Samples $(10 \mathrm{ml})$ were filtered using $0.2 \mu \mathrm{m}$ pore size polycarbonate filters (Nuclepore) and stored frozen at $-20^{\circ} \mathrm{C}$ until analysis. Concentrations of dissolved free neutral monosac- charides (DFCHO) were analysed by HPLC using a Carbopac PA 10 column (Dionex) and pulsed amperometric detection according to Mopper et al. (1992). In general, 2 injections per sample were analysed. We used $20 \mathrm{mM} \mathrm{NaOH}$ as eluent. Prior to analysis, samples were desalted by ion-exchange chromatography according to Borch \& Kirchman (1997). Dissolved combined neutral monosaccharides (DCCHO) were analysed by HPLC as DFCHO after $20 \mathrm{~h}$ of hydrolysis with $0.09 \mathrm{~N} \mathrm{HCl}$ at $100^{\circ} \mathrm{C}$.

TEP and CSP. Subsamples $(2 \mathrm{ml})$ were filtered in duplicates onto polycarbonate membranes $(0.2 \mu \mathrm{m}$ pore size) under low vacuum ( $<10$ mbar) to enumerate TEP and CSP. TEP samples were stained with $0.22 \mu \mathrm{m}$ pre-filtered $0.02 \%$ Alcian Blue prepared in $0.06 \%$ glacial acetic acid (pH 2.5) (Alldredge et al. 1993). CSP samples, which were available only until Day 11, were stained with $1 \mathrm{ml}$ of $0.04 \%$ Coomassie Brilliant Blue (G-250) according to Long \& Azam (1996). Samples were filtered dry, placed over a drop of oil on a frosted slide (Cytoclear TM, Poretics) and enumerated using a Zeiss Axioplan microscope under bright field illumination $(100 \times$ to $200 \times$ magnification). Image analysis (analySIS V 3.0, Soft Imaging System) was used to assess the equivalent spherical area of TEP and CSP.

Statistical analyses. Statistical analyses were done by 'post hoc' standard least square contrast analyses after ANCOVA, with time as the covariate and culture type as the nominal predictor. All statistical analyses were performed with the software JMP 4.02 using average values. Significance was given at p-values $<0.05$.

\section{RESULTS}

\section{Phytoplankton and bacterial abundance}

Abundances of living and dead Thalassiosira rotula greatly differed between axenic and non-axenic cultures and between cultures incubated in $f / 2$ and $f / 10$ media (Fig. 1A, B, Table 1). The onset of growth in the axenic $f / 2 T$. rotula culture was delayed by $10 \mathrm{~d}$ relative to that in the $f / 10$ medium, even though maximum numbers were similar in both treatments. In contrast, in the presence of the natural marine bacterial community, the onset of algal growth occurred much faster in the $f / 2$ than in the $f / 10$ medium. During the whole experiment we did not observe any small phytoplankton, cyanobacteria, or protozoa that may have slipped through the $5 \mu \mathrm{m}$ Nuclepore membranes. The presence of HP50 led to persistently high algal numbers in the $f / 2$ medium, whereas no algal growth was observed in the respective $f / 10$ culture. The isolate HP48 inhibited growth of $T$. rotula in the 
Table 1. Thalassiosira rotula. To test for significant differences between axenic and non-axenic cultures of the diatom in $f / 2$ and f/10 media, statistical analyses using 'post hoc' analyses after ANCOVA, with time as the covariate and culture as the nominal predictor, were performed with the software JMP 4.02. DOC: dissolved organic carbon; DFAA: dissolved free amino acids; DCAA: dissolved combined amino acids; DFCHO: dissolved free neutral monosaccharides; DCCHO: dissolved combined neutral monosaccharides; TEP: transparent exopolymer particles; NS: not significant

\begin{tabular}{|lcc|}
\hline & \multicolumn{2}{c|}{ Significance value } \\
& $f / 2$ & $f / 10$ \\
\hline Living algae & $<0.0001$ & $<0.0001$ \\
Dead algae & 0.0224 & $<0.0001$ \\
Free bacteria & $<0.0001$ & $<0.0001$ \\
Attached bacteria & $<0.0001$ & $<0.0001$ \\
DOC & $\mathrm{NS}$ & $\mathrm{NS}$ \\
DFAA & 0.0472 & 0.0309 \\
DCAA & $\mathrm{NS}$ & 0.0111 \\
DFCHO & $\mathrm{NS}$ & $\mathrm{NS}$ \\
DCCHO & $\mathrm{NS}$ & 0.0079 \\
TEP & 0.0019 & $<0.0001$ \\
& & \\
\hline
\end{tabular}

f/2 medium completely, but led to persistently high algal numbers in the $f / 10$ medium. The isolate HP49 prevented growth of $T$. rotula completely in both media.

Numbers of free and attached bacteria also varied significantly among the different treatments and media (Fig. 1A,B, Table 1). The abundance of free-living cells in the natural bacterial community increased in both media together with algal cell numbers. Numbers declined after the algal peak in the $f / 2$ medium, but persisted at an enhanced level in the $f / 10$ medium (Fig. 1A,B). The abundance of attached bacteria in this treatment peaked during the decline of algal cell numbers in both media and decreased thereafter. Numbers of free and attached HP50 in the algal f/2 culture continuously increased during the incubation period and reached the highest values of all treatments, thus responding to the high algal cell numbers in this treatment. In the respective $f / 10$ culture with no algal growth, the cell numbers of HP50 remained low. Free and attached bacteria of the isolate HP49, preventing algal growth in both media, also remained low throughout the whole incubation. This was also true for the isolate HP48 in the $f / 2$ culture; however, in the $f / 10$ culture, the numbers of free and attached HP48 constantly increased, thus responding to the algal growth in this treatment.

In both media - that initially axenic and that inoculated with axenic algae - free and attached bacteria were detected on Days 25 and 30, indicating that the axenic control tanks became contaminated by bacteria on the last 2 sampling dates.

\section{Dissolved organic carbon}

Concentrations of DOC did not significantly differ between the various treatments, but they did vary with medium (Fig. 2A,B, Table 1). Initial concentrations of DOC in the $f / 2$ medium, however, were substantially higher than in the $f / 10$ medium (Fig. 2A). DOC measurements of the compounds added (such as vitamins and EDTA) to the medium revealed that the 5-fold higher concentrations of these compounds in the $f / 2$ medium accounted for an additional input of ca. $150 \mu \mathrm{M}$ DOC in comparison to the $f / 10$ medium. In the $f / 2$ culture, with the natural bacterial community, initial DOC concentrations were reduced and remained low during the main growth phase of the alga and bacteria until Day 11 and increased thereafter, covarying with the axenic treatment (Fig. 2A). In the $f / 10$ medium of this treatment, with low bacterial growth, DOC concentrations increased and peaked together with algal cell numbers. In the cultures to which bacterial isolates were added, DOC concentrations increased systematically only in those treatments in which algal growth was promoted, i.e. in the treatment with HP50 in f/2 medium and that with HP48 in f/10 medium. In the other cultures, DOC concentrations fluctuated independently of the growth of the alga and the bacterial isolate.

\section{Dissolved amino acids}

In the Thalassiosira rotula cultures, in which algal growth was detected, the dynamics of DFAA concentrations co-varied with those of algal numbers, i.e. in the axenic treatments and in those inoculated with natural bacteria, in $f / 2$ culture with the isolate HP50 and in $f / 10$ culture with HP48 (Fig. 3A,B,E,F). The dynamics of DFAA concentrations in the axenic $f / 10$ culture and in the culture inoculated with the natural bacterial community lagged a few days behind the dynamics of algal cell numbers. DFAA concentrations in the axenic $f / 10$ culture were substantially higher than in the culture with the natural bacterial community towards the end of the incubation. Interestingly, highest concentrations occurred in the f/10 culture inoculated with HP48, showing persistently high algal numbers with 2 distinct peaks at Days 11 and 25 (Fig. 3F). In the other cultures inoculated with bacterial isolates and no or low algal growth, DFAA concentrations always remained low.

Average compositions (mol\%) of DFAA in axenic $f / 2$ and $f / 10$ Thalassiosira rotula cultures were almost the same, with aspartate, glutamate and serine representing 15 to $18 \%, 17$ to $20 \%$ and 20 to $21 \%$, respectively. The presence of bacteria in T. rotula cultures with high 


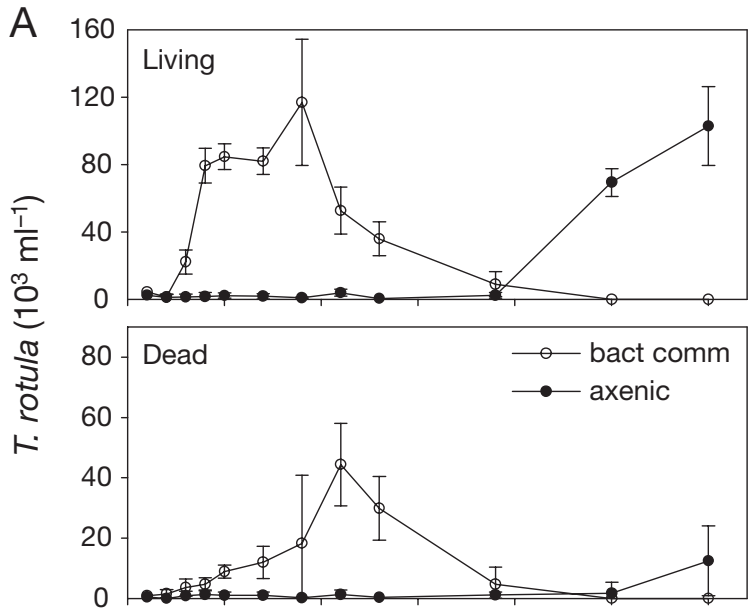

$f / 2$
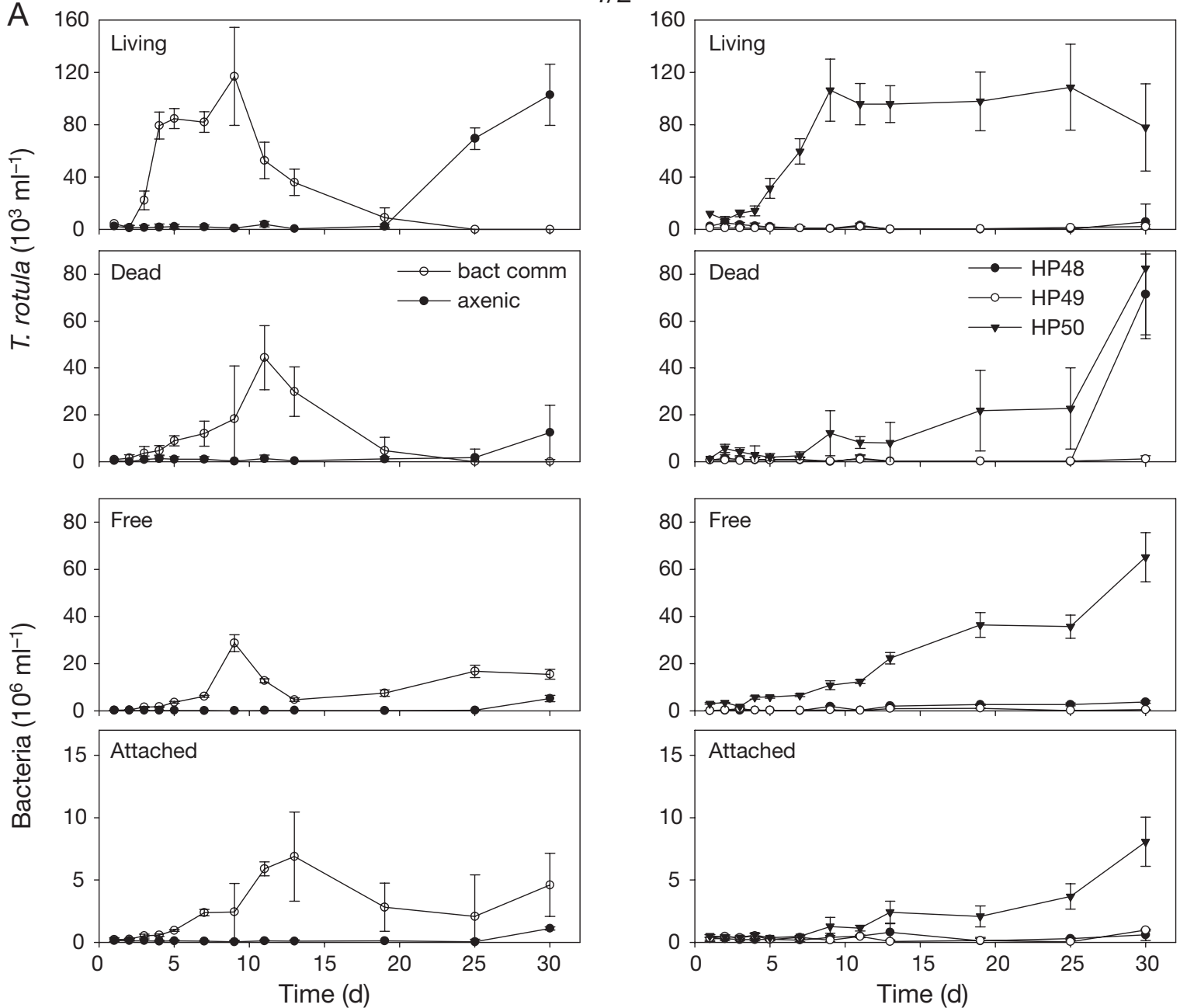

Fig. 1 (and overleaf). Thalassiosira rotula. Numbers of living and dead diatoms as well as free and attached bacteria grown in (A) $f / 2$ and (B) f/10 media without (axenic) and inoculated with a natural bacterial community (bact comm) or bacterial isolates HP48, HP49 and HP50. Error bars: SD of 3 independent measurements for each given parameter

algal growth $(f / 2$ and $f / 10$ cultures with natural bacteria, $f / 2$ culture with the isolate HP50 and $f / 10$ culture with HP48) resulted in increased mol\% of aspartate and glutamate (up to $45 \%$ ) and in reduced mol\% of serine $(\leq 15 \%)$, compared to the axenic cultures. In non-axenic cultures with low or no algal growth $(f / 2$ cultures with HP48 or HP49 and f/10 cultures with HP49 or HP50) the mol\% of aspartate and glutamate was reduced $(<40 \%)$ and that of serine was increased $(\geq 25 \%)$.

The concentration dynamics of DCAA in the axenic treatments and in those inoculated with natural bacteria in both media as well as in those inoculated with HP50 in f/2 medium and HP48 in f/10 medium were, in general, similar to the dynamics of DFAA (Fig. 3C,D,G,H). In the treatment with the natural bacterial community in $f / 2$ medium, however, highest DCAA concentrations occurred in the second half of the experiment. At this time, algal and bacterial numbers decreased. In the Thalassiosira rotula cultures growing in $f / 2$ medium and inoculated with the isolates HP48 and HP49, DCAA concentrations also increased in the second half of the experiment, whereas they did not increase in the respective $f / 10$ cultures (Fig. 3D,F).

In contrast to DFAA, DCAA were characterised by a higher $\mathrm{mol} \%$ of glycine/threonine, $B$-alanine and alanine (10 to $15 \%$ each). In all non-axenic algal cultures with high algal growth $(f / 2$ and $f / 10$ cultures with natural bacteria, $f / 2$ culture with the isolate HP50 and f/10 culture with HP48) the mol\% of aspartate and glutamate was increased $(>25 \%)$, whereas the values for glycine/threonine and $ß$-alanine were reduced (10 to $15 \%)$, compared to the axenic cultures. In non-axenic cultures with low or no algal growth (f/2 cultures with HP48 or HP49 and f/10 cul- 


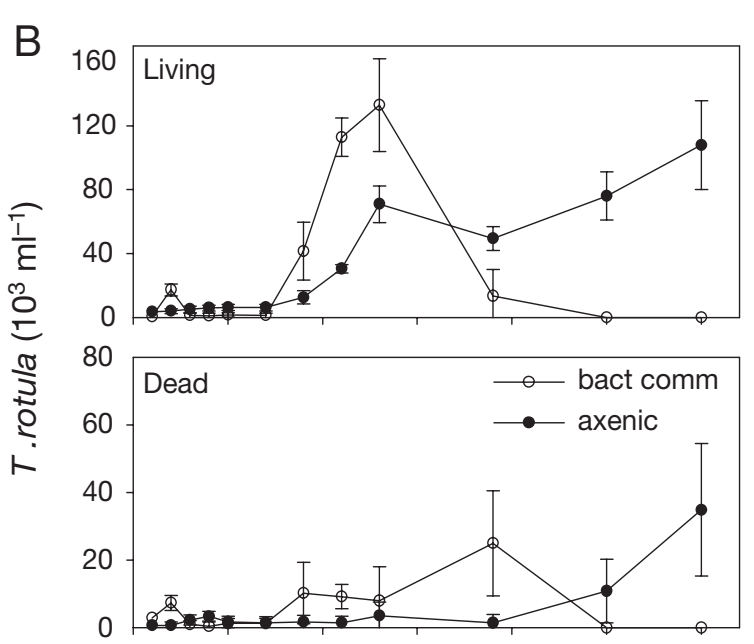

$f / 10$
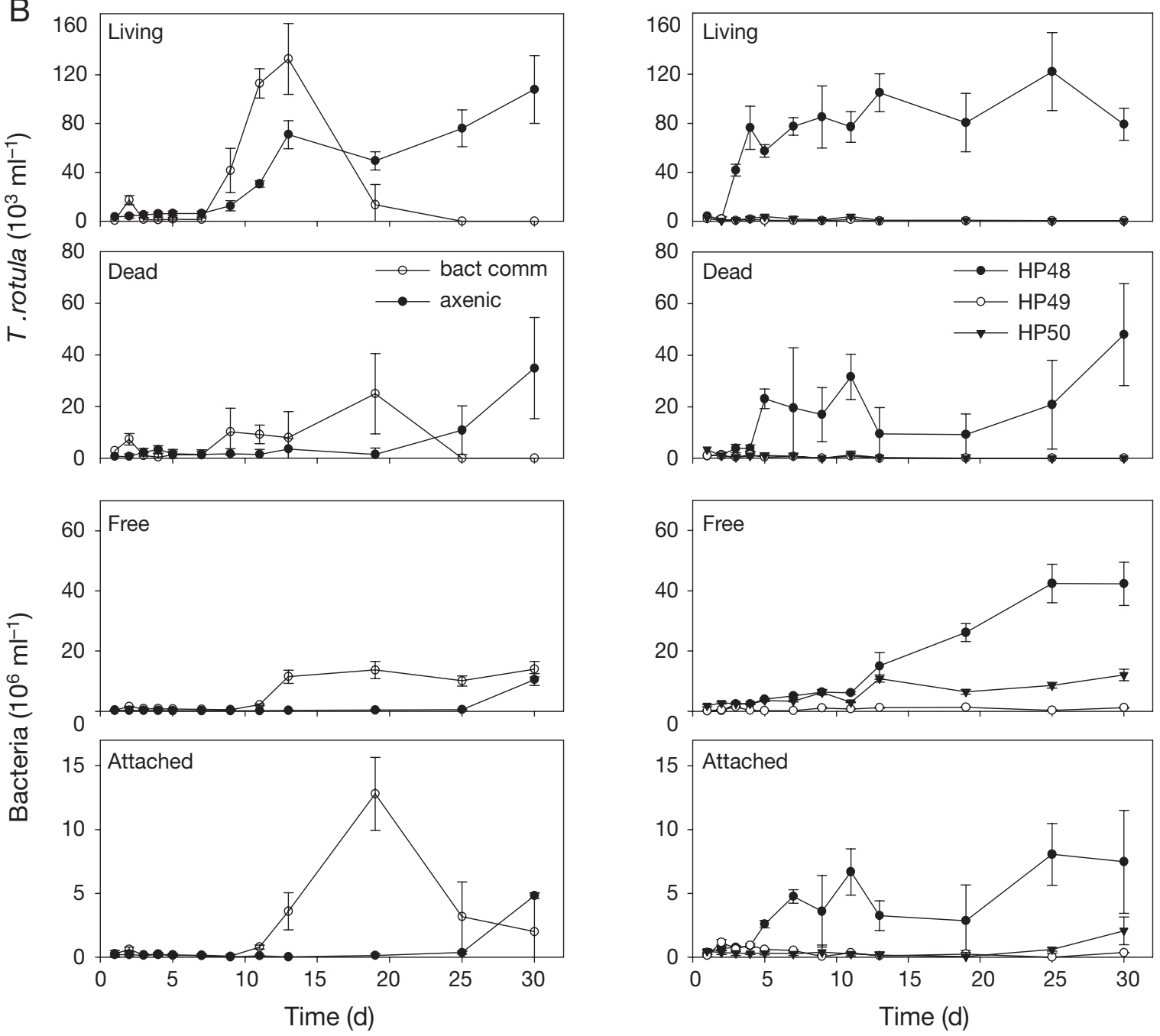

Fig. 1 (continued)

tures with HP49 or HP50) the mol\% of aspartate and glutamate $(<10 \%)$ was reduced, whereas the values for serine, glycine/threonine and $\beta$-alanine were increased $(\geq 50 \%)$. These results indicate that algal exudation and bacterial hydrolysis may affect DCAA $\mathrm{mol} \%$ in different ways.

\section{Dissolved carbohydrates}

Concentrations of DFCHO remained low and without fluctuations in the axenic f/2 Thalassiosira rotula culture and in those inoculated with natural bacteria (Fig. $4 \mathrm{~A}, \mathrm{E}$ ). In the axenic $f / 10$ culture, DFCHO concentrations increased between Days 16 and 25 after the alga started growing (Fig. 4E) and before the culture became non-axenic. High concentrations of DFCHO also occurred in the $f / 10$ culture of isolate HP48 over most of the incubation period, especially when algal numbers were high. In all other cultures with bacterial isolates, DFCHO concentrations remained low, except on Day 25, and independent of the growth dynamics of the alga (Fig. 4B,F). DFCHO in all cultures consisted of $>80 \%$ of glucose and showed only little variation with time and among the different treatments.

Concentrations of DCCHO in axenic cultures remained lower than concentrations in cultures inoculated with the natural bacterial community (Fig. 4C,G). In the $f / 2$ culture with natural bacteria, DCCHO concentrations increased when algal numbers declined. In the axenic culture, as well as in that with natural bacteria in $f / 10$ medium, however, DCCHO concentrations already increased during the growth phase and remained higher thereafter. In the $f / 2$ culture with the isolate HP50, promoting algal growth, DCCHO concentrations were higher than in the respective cultures 

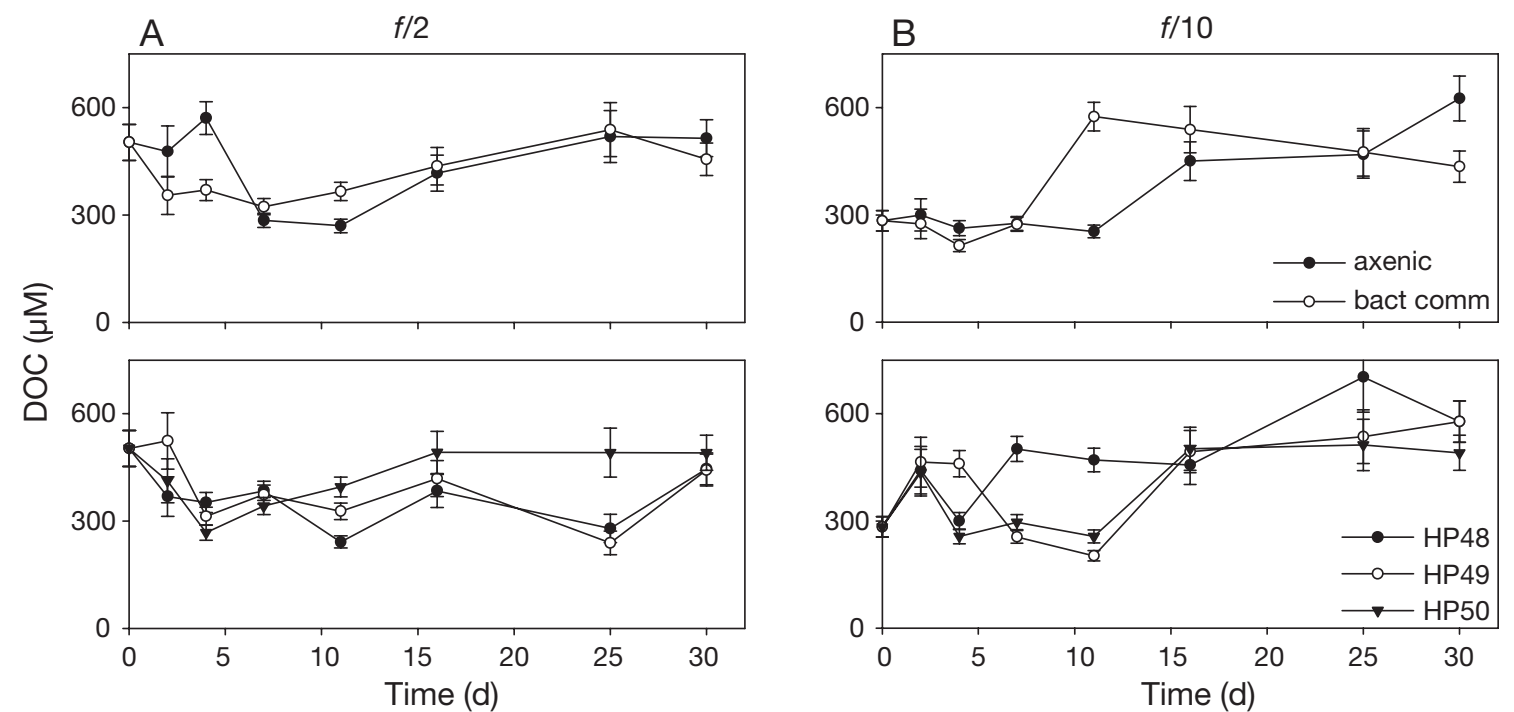

Fig. 2. Thalassiosira rotula. Concentrations of dissolved organic carbon (DOC) in cultures of the diatom grown in (A) $f / 2$ and (B) f/10 media without (axenic) and inoculated with a natural bacterial community (bact comm) or bacterial isolates HP48,

HP49 and HP50. Error bars: SD (as in Fig. 1)
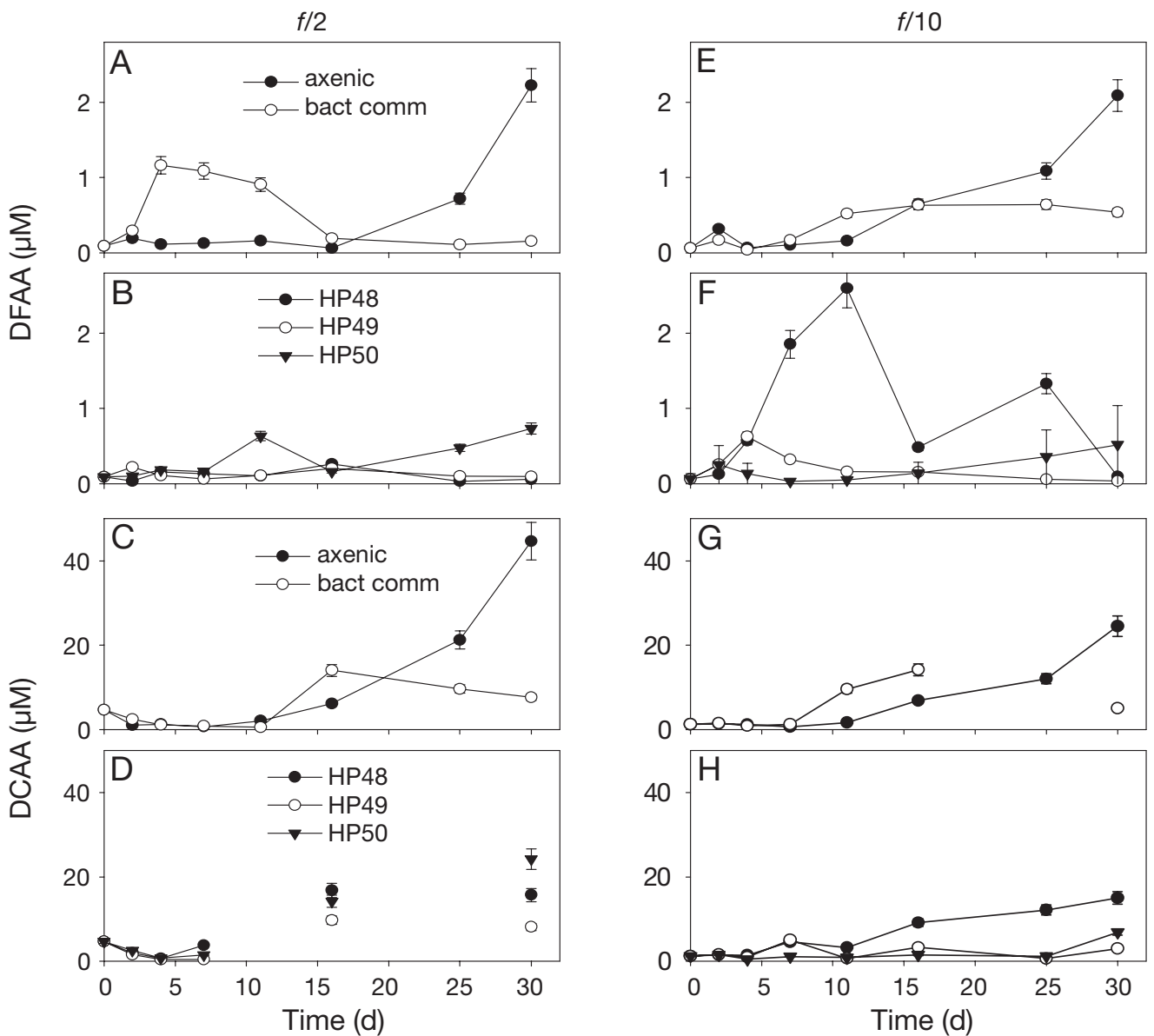

Fig. 3. Thalassiosira rotula. Concentrations of dissolved free amino acids (DFAA) and dissolved combined amino acids (DCAA) in cultures of the diatom grown in $f / 2$ and $f / 10$ media. (A,E) DFAA in axenic and bacterial community-inoculated (bact comm) cultures; (B,F) DFAA in cultures inoculated with the bacterial isolates HP48, HP49 and HP50; (C,G) DCAA in axenic and bacterial community-inoculated cultures; and $(\mathrm{D}, \mathrm{H})$ DCAA in cultures inoculated with the bacterial isolates HP48, HP49 and HP50. 

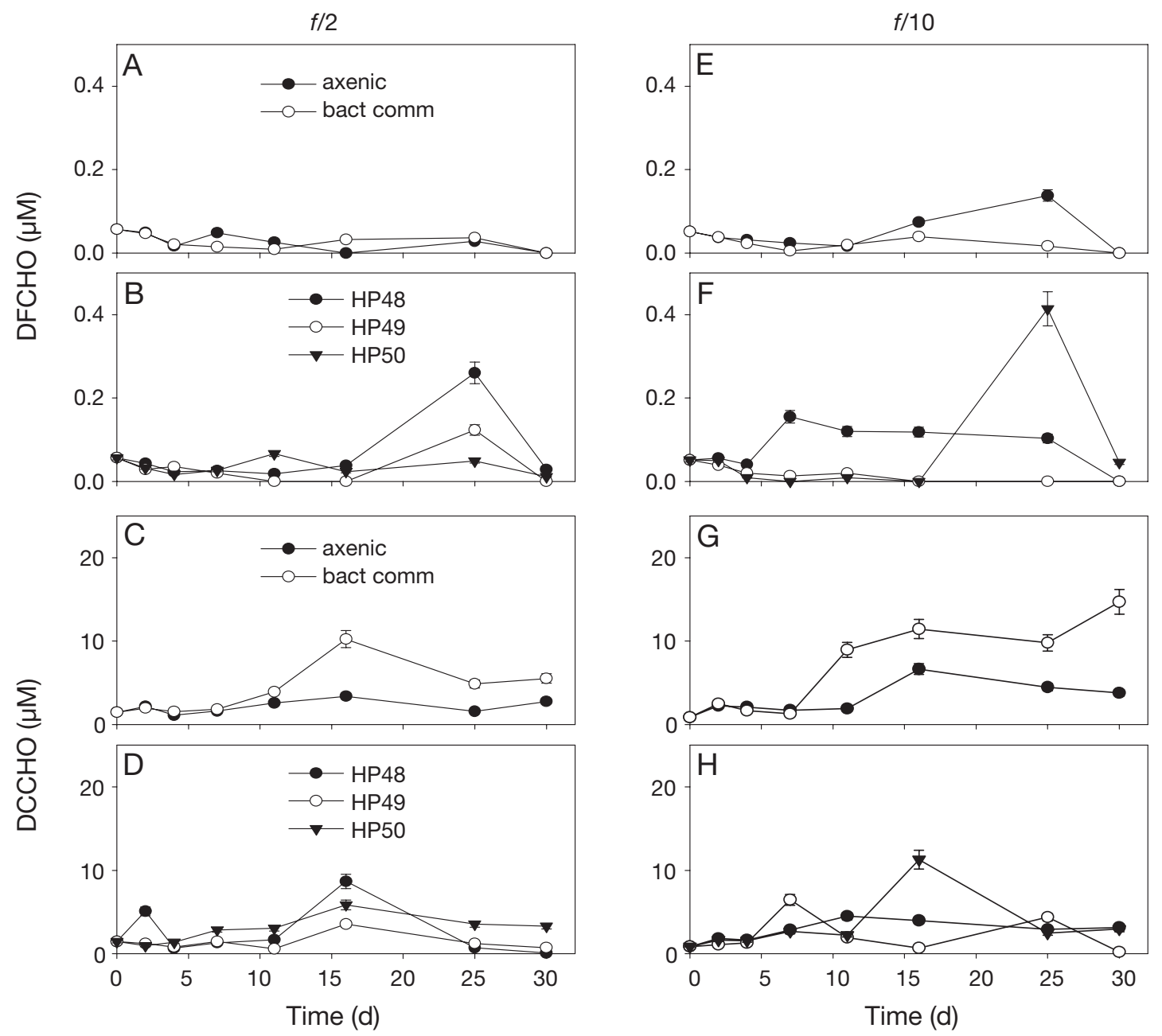

Fig. 4. Thalassiosira rotula. Concentrations of dissolved free neutral monosaccharides (DFCHO) and dissolved combined neutral monosaccharides (DCCHO) in cultures of the diatom grown in $f / 2$ and $f / 10$ media. (A,E) DFCHO in axenic and bacterial community-inoculated (bact comm) cultures; (B,F) DFCHO in cultures inoculated with the bacterial isolates HP48, HP49 and HP50; $(\mathrm{C}, \mathrm{G}) \mathrm{DCCHO}$ in axenic and bacterial community-inoculated cultures; and $(\mathrm{D}, \mathrm{H}) \mathrm{DCCHO}$ in cultures inoculated with the bacterial isolates HP48, HP49 and HP50. Error bars: SD (as in Fig. 1)

inoculated with the other isolates, except on Day 16, when a single value with HP48 exceeded the other values (Fig. 4D). Generally, DCCHO concentrations remained low in the treatments with $f / 2$ medium and bacterial isolates in which algal growth was inhibited (Fig. 4D). In $f / 10$ cultures inoculated with bacterial isolates, DCCHO concentrations fluctuated without any relationship to the growth of the alga or bacteria (Fig. 4H).

Average mol\% compositions of DCCHO in axenic $f / 2$ and $f / 10$ Thalassiosira rotula cultures were very similar, with glucose and mannose contributing 65 to $70 \%$ and 15 to $18 \%$, respectively. In non-axenic algal cultures with high algal growth $(f / 2$ and $f / 10$ cultures with natural bacteria, $f / 2$ culture with the isolate HP50 and f/10 culture with HP48) the mol\% of glucose was decreased $(<50 \%)$, whereas the values of fucose and mannose were increased (>10 and $20 \%$, respectively). In non-axenic cultures with low or no algal growth $(f / 2$ cultures with the isolate HP48 or HP49 and f/10 cultures with HP49 or HP50) the mol\% of glucose increased $(>70 \%)$, whereas that of mannose decreased $(<10 \%)$.

\section{Transparent exopolymer particles}

All Thalassiosira rotula cultures that exhibited significant growth produced TEP, even though pronounced differences were recorded (Fig. 5, Table 1). Highest abundances of TEP occurred in $f / 2$ cultures inoculated with natural bacteria and with the isolate HP50 and in the $f / 10$ culture inoculated with the isolate HP48. In all these cultures, but also in the f/10 culture 

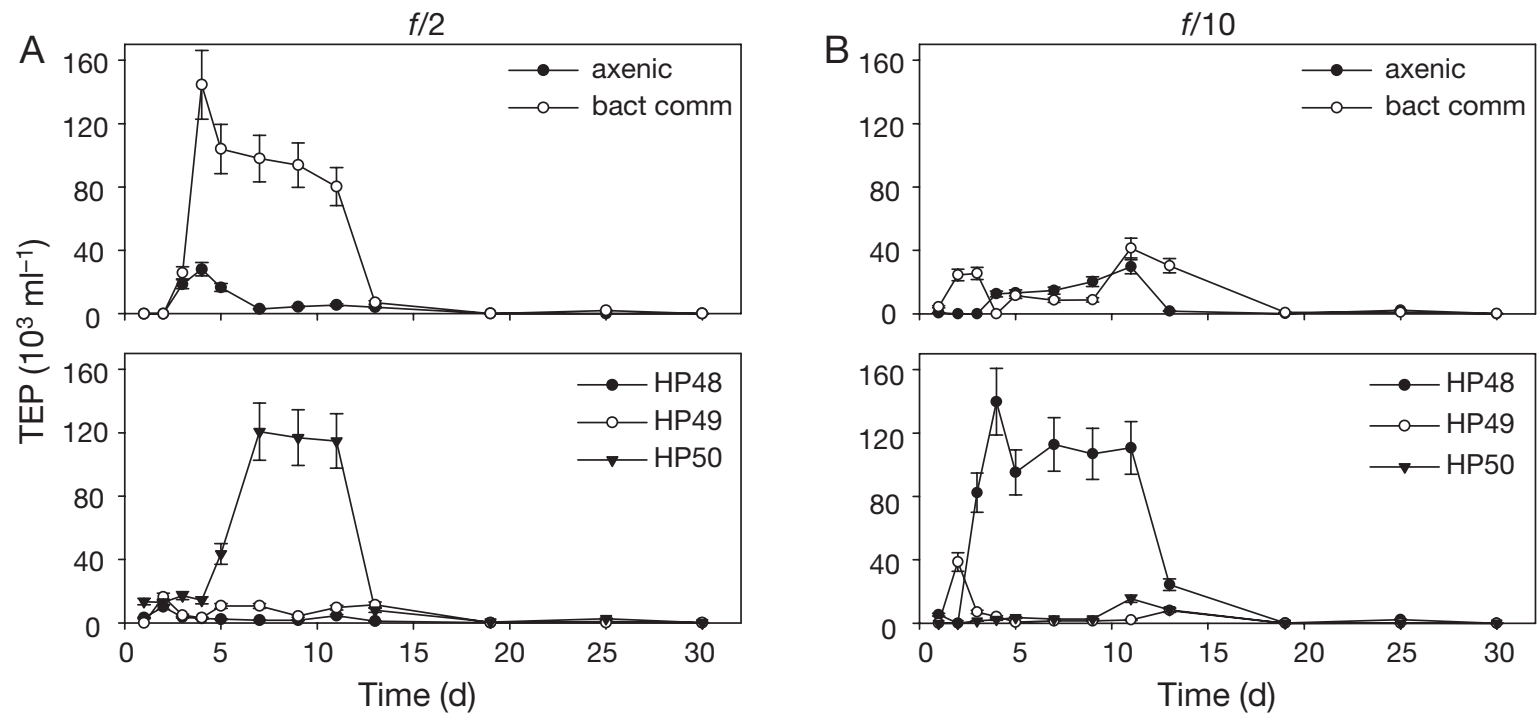

Fig. 5. Thalassiosira rotula. Abundance of transparent exopolymer particles (TEP) in cultures of the diatom grown in (A) f/2 and (B) f/10 media without (axenic) and inoculated with a natural bacterial community (bact comm) or the bacterial isolates HP48, HP49 and HP50. Error bars: SD (as in Fig. 1)

with the natural bacterial community, TEP abundance strongly decreased when the bacterial growth phase began. This decrease occurred irrespective of whether algal numbers declined, as in the $f / 2$ and $f / 10$ cultures with the natural bacterial community, or remained high, like in the 2 cultures with the bacterial isolates. Axenic cultures produced substantially less TEP and only in the early growth phase (Fig. 5A,B). In the cultures inoculated with bacterial isolates that inhibited algal growth, TEP abundance always remained low (Fig. 5A,B).

\section{Coomassie Brilliant Blue-stainable particles}

CSP were only monitored until Day 11 of the experiment, and no significant differences were found between $f / 2$ and $f / 10$ cultures (Table 1 ). Axenic $f / 2$ cultures as well as f/10 cultures of Thalassiosira rotula did not show any production of CSP until Day 11. In contrast, in the $f / 2$ cultures inoculated with the natural bacterial community, numbers of CSP increased from Day 5 to 11. This increase paralleled that of dead algal cells, which reached a maximum on Day 11 . In the respective $f / 10$ culture, the number of CSP remained very low until Day 11, but highest algal numbers only occurred on Day 13 (Fig. 1B). In the f/10 culture inoculated with the isolate HP48, leading to high algal numbers (Fig. 1B), CSP abundance remained low at the beginning but greatly increased on Day 11. CSP numbers remained very low in all cultures inoculated with bacterial isolates that inhibited algal growth.

\section{DISCUSSION}

\section{Interactions of bacteria and Thalassiosira rotula}

Our results show that different bacteria affected the growth of Thalassiosira rotula very differently, and that the strain-specific effects were also dependent on environmental conditions such as concentrations of nutrients, vitamins and trace metals. The presence of a natural bacterial community collected from a coastal marine site, the Wadden Sea, promoted growth of this alga in $f / 2$ as well as in $f / 10$ medium. In $f / 2$ medium, promotion was such that algal growth started much earlier than in the axenic culture, whereas in $\mathrm{f} / 10$ medium promotion resulted in higher cell numbers than in the axenic culture without any time shift in the onset of algal growth. Inoculation with natural bacteria always prevented accumulation of algal cells after the peak of the algal bloom, presumably by ectoenzymatic lysis of the alga (Grossart et al. 2006a). This change in function of the mixed bacterial community may have been linked to changes in bacterial community composition. In fact, in a comparable study, we have shown that a succession of the bacterial community took place during the growth of a $T$. rotula culture, leading to the dominance of Sphingobacteria/Flavobacteria and enhanced proportions of alpha- and gammaproteobacteria in the particle-associated fraction during the late exponential and stationary phases (Grossart et al. 2005). This succession has important implications for the modes of interactions between the alga and the bacteria present (Grossart et al. 2005, 2006a). We 
hypothesise that the breakdown of the algal culture was mainly a result of nutrient stress and subsequent bacterial decomposition. Similarly, declines in the abundance of free-living and attached bacteria may have been a result of the reduced availability of organic substrates. However, phage infection and protozoan grazing may have contributed to this decline and succession in community composition. Our microscopic observations (even with Sybr Gold staining, H. P. Grossart unpubl. data), however, do not give any hint that viral lysis or grazing have been important in our experimental setup.

The addition of single bacterial isolates, also obtained from Thalassiosira rotula cultures inoculated with bacteria from the Wadden Sea, resulted either in almost complete growth inhibition of the alga (HP49) or in growth promotion in f/2 (HP50) or f/10 medium (HP48). These different growth patterns of the alga as a function of the presence of single bacterial isolates support our observation that modes of interactions between algae and bacteria vary with changes in bacterial community structure and environmental conditions. It has been previously shown that (1) environment and source community of bacteria control availability of nutrients, vitamins and trace metals (Grossart 1999), (2) complex bacterial communities tend to vary over time and with algal growth (Lebaron et al. 1999, Schäfer et al. 2002, Pinhassi et al. 2004, Grossart et al. 2005), and (3) the presence of different bacteria effects algal exudation and organic matter dynamics in different ways (Grossart et al. 2006a).

We have no direct indications of which controlling factors changed under the varying growth conditions, except that concentrations of inorganic nutrients, vitamins and trace elements differed by a factor of 5 . This apparently rather small difference obviously induced major changes in the physiology of the alga and/or bacteria, leading to such strikingly different interactions. In addition to these differences, bacteria may have changed the availability of inorganic carbon and affected $\mathrm{pH}$ in the microenvironment of the alga. Both factors are well known to affect algal growth (e.g. Gavis \& Ferguson 1975). We did not assess inorganic carbon and $\mathrm{pH}$ in the microenvironment of the alga, and assume that these factors were of minor importance in controlling the growth of Thalassiosira rotula. Maximum algal numbers were rather similar in both assays and had not yet reached the stationary phase in the axenic treatments, indicating that the availability of inorganic carbon was not limiting.

The given conditions may have been favourable for some isolates to produce growth-promoting substances such as vitamins (Pringsheim 1912, Haines \& Guillard 1974). Growth inhibition of the alga could have been caused by (1) production of antibiotic substances by the bacteria (Cole 1982, Imai et al. 1993), (2) synthesis of very effective ectoenzymes hydrolysing the algae (Martinez et al. 1996, Bidle \& Azam 2001), and (3) competition for inorganic nutrients (Rhee 1972, Thingstad et al. 1993, Guerrini et al. 1998) and/or lack of vitamins and trace elements (Grossart 1999). These properties and different modes of interactions have been reported for various bacteria, but not for single bacterial isolates growing at different growth conditions.

Our experiments were performed with a single Thalassiosira rotula culture. Hence, the algal bacterial interactions we observed may be typical for this alga, but not necessarily for other algae. In fact, we have shown that modes of interactions and composition of mixed bacterial communities, mainly attached bacterial subcommunities, differ throughout growth of $T$. rotula and Skeletonema costatum batch cultures (Grossart et al. 2005, 2006a). Hence, and as outlined above, specific interactions of algae and bacteria appear to be general phenomena, and further studies may reveal other modes or modifications of interactions between algae and heterotrophic bacteria.

\section{Potential role of specific isolates}

Isolates HP48 and HP50 are both members of the family Rhodobacteriaceae, but exhibit completely different interactions with Thalassiosira rotula and indicate that specific physiological properties mediate these interactions. The isolate HP48 affiliates to the marine prosthecate and budding Hyphomonas group and is closely related to the marine alphaproteobacterium HP40 (Grossart et al. 2004). So far, only little is known about the physiology of this marine bacterium, which often exhibits a surface-associated life style (Weiner et al. 2000). Members of this group have also been detected during phytoplankton blooms in the Southern California Bight and the North Sea (Fandino et al. 2001, Pinhassi et al. 2003).

The isolate HP50 belongs to the Roseobacter clade, which is often affiliated with phytoplankton blooms (Zubkov et al. 2001, Pinhassi et al. 2004, Grossart et al. 2005). There are good indications that 1 factor for close interactions between this bacterial group and specific algal communities is the release of dimethylsulfoniumpropionate (Zubkov et al. 2001). Our results suggest that this bacterial group also favours phytoplankton growth.

The isolate HP49 affiliates to the Sphingobacteria and is closely related to the marine Flexibacterium HP34 (Grossart et al. 2004). Bacteroidetes can greatly dominate the attached fraction of bacteria on marine phytoplankton (Fandino et al. 2001, Schäfer et al. 2002, Pinhassi et al. 2004, Grossart et al. 2005), and are capa- 


f/10

Fig. 6. Schematic summary of the major differences between the various approaches used. $(\bigcirc)$ diatoms; $(\nabla)$ bacteria; bact Comm: natural bacterial community; HP48, HP49 and HP50: bacterial isolates; bac. degr.: bacterial degradation; CSP: Coumassie Blue-stainable particles; for other abbreviations, see Table 1

ble of degrading a variety of polymeric substrates (Kirchman 2002). In addition, a high algicidal activity has been reported for this bacterial group (Mayali \& Azam 2004) and may explain growth inhibition of Thalassiosira rotula by this isolate.

\section{Dynamics of DOM}

Bacteria affected the dynamics of DOC, amino acids and the carbohydrates of Thalassiosira rotula, in different and highly specific ways as can be seen by comparing axenic versus non-axenic cultures (Fig. 6). The observed variable patterns of DOM dynamics may be due to changes in release as well as selective decomposition and removal by bacteria. For example, the much higher DOC concentration on Day 11 in the f/10 culture with mixed natural bacteria compared to that without bacteria indicates stimulation of DOC release in the presence of these bacteria. After Day 11, DOC concentrations continuously decreased in the presence of natural bacteria, but continuously increased in the absence of bacteria, indicating bacterial decomposition and removal of DOC. Since DOC release and removal may take place at the same time in our non-axenic cultures, we were not able to clearly distinguish between these 2 opposing processes. However, concentrations of DOC always decreased when bacterial numbers and presumably bacterial decomposition was high, e.g. in the early breakdown phase of the alga in $f / 2$ cultures inoculated with natural bacteria.

Cultures with single bacterial isolates showed pronounced differences in DOC dynamics depending both on the presence of specific bacteria and environmental conditions. For example, the presence of HP50 in $f / 2$ cultures led to removal of DOC, whereas in $f / 10$ cultures, where bacterial numbers remained low, release of DOC increased throughout the incubation even though algal numbers were low. This evidence indicates that bacterial DOC utilisation requires sufficiently high levels of inorganic nutrients (Stoderegger \& Herndl 1999) and presumably vitamins and trace metals. In addition, bacteria may actively transform 
DOC into particulate organic carbon, e.g. generate TEP (Passow 2002a), especially when concentrations of inorganic nutrients and trace metals are low.

DFAA accumulated in the axenic cultures over time, and concentrations co-varied with algal and bacterial dynamics. Highest concentrations occurred in periods when high numbers of bacteria were recorded ( $f / 2$ cultures with natural bacteria and with the isolate HP50, and $f / 10$ culture with the isolate HP48). Because axenic Thalassiosira rotula do not release substantial amounts of DFAA (Grossart et al. 2006a), the high concentrations were most likely a result of intense DCAA hydrolysis. This notion is supported by the fact that non-axenic cultures with high algal growth ( $f / 2$ and $f / 10$ cultures with natural bacteria, f/2 culture with HP50 and f/10 culture with HP48) showed a different DFAA mol\% composition than those with low or no algal growth. These findings indicate that algal exudation, bacterial hydrolysis and DFAA uptake not only affect the quantity (Grossart et al. 2006a), but also the composition of DFAA.

DCAA accumulated over time in the axenic cultures, but also in the other cultures in which the growth of Thalassiosira rotula was promoted by bacteria. This accumulation was a result of the breakdown of algal biomass, i.e. lysis and bacterial decomposition. In both algal cultures inoculated with natural bacteria, DCAA accumulation was less pronounced, reflecting more intense decomposition and consumption by the mixed bacterial community. As for DFAA, the mol\% composition of DCAA in all non-axenic algal cultures with high algal growth was different from that in non-axenic cultures with low or no algal growth. Because phytoplankton blooms have a reduced long-term impact on the composition of amino acids in the sea (Meon \& Kirchman 2001), degradation pathways by bacteria seem to be more important than production processes in determining the molecular composition of amino acids in marine pelagic systems.

Whereas DFCHO concentrations remained low in most cultures, DCCHO accumulated in cultures inoculated with bacteria, but also in the axenic f/10 culture. DCCHO concentrations were higher in cultures with natural bacteria compared to those in which algal growth was promoted by the isolates HP48 and HP50. These results indicate that the alga growing in $f / 10$ medium released some DCCHO without any bacterial impact and that the bacterially promoted growth resulted in enhanced DCCHO release under these conditions. Furthermore, the isolates consumed some DCCHO, mainly towards the end of the experiment. On the other hand, the mixed bacterial community even released DCCHO, mainly in the f/10 medium. Similarly to amino acid dynamics, algal exudation and bacterial removal led to changes in the quantity and quality of DCCHO.

\section{Dynamics of microparticles}

Formation of TEP predominantly occurred in the growing algal cultures, irrespective of the type of bacteria present, but disappeared when the bacteria started growing. This result suggests that TEP was mainly of algal origin and that the presence of bacteria favoured its formation but also its degradation. It has been shown that natural marine bacterioplankton is capable of producing significant amounts of exopolymeric substances (Stoderegger \& Herndl 1999), which may increase the concentration of TEP (Passow $2002 b)$. On the other hand, marine bacteria are known to hydrolyse exopolymers such as TEP (Passow 2002a). Another possibility for the disappearance of TEP in our experiments would be aggregate formation. However, from our macroscopic and microscopic observations we do not have any indications of massive aggregation. Therefore, we assume that bacterial decomposition was the major sink for TEP, suggesting that the TEP we detected were not recalcitrant, as postulated for the TEP-mediating aggregation (Passow 2002b).

CSP were consistently detected only in those cultures in which dead algae occurred, which suggests that algal death due to bacterial hydrolysis led to the appearance of CSP. It has previously been shown that CSP are decomposed by bacteria in various pelagic ecosystems (Long \& Azam 1996, Berman \& VinerMozzini 2001), but our observation adds to published reports that CSP are also formed from decaying algae. In more complex marine food webs other decaying organisms releasing protein-containing particles, such as zooplankton and bacteria, may also contribute to the formation of CSP.

\section{CONCLUSIONS}

We have shown that algal bacterial interactions are very specific, strongly affecting algal growth, and that they depend on environmental conditions such as concentrations of inorganic nutrients, vitamins and trace metals (Fig. 6). The mode of interaction of individual bacteria can change at varying growth conditions at least for Thalassiosira rotula, but presumably also for other algae. The presence of specific bacterial communities and environmental conditions led to pronounced changes in the quantity and quality of phytoplanktonderived DOM and microparticles. Natural bacterial communities promote algal growth in the early, i.e. exponential, growth phase, but transitionally turn into a competitive and parasitic life style, leading to the breakdown of the algal bloom. Our experiments with single isolates indicate that various modes of interac- 
tion within a given bacterial community occur, even with a single alga. In the field these interactions are much more complex, as they also include reactions among various bacteria (Long \& Azam 2001, Grossart et al. 2004), as well as temporal changes in the composition and activities of bacterial and phytoplankton communities.

Acknowledgements. We appreciate the technical assistance of Birgit Kürzel and Rolf Weinert for neutral monosaccharide analysis. We further thank Gertje Czub for abundance measurements of algae, bacteria, TEP and CSP. The work was performed within the Research Group BioGeoChemistry of the Wadden Sea (FG 432-TP5), supported by the Deutsche Forschungsgemeinschaft (DFG).

\section{LITERATURE CITED}

Alldredge AL, Passow U, Logan BE (1993) The existence, abundance and significance of large transparent exopolymer particles in the ocean. Deep-Sea Res 40:1131-1140

Baines SB, Pace ML (1991) The production of dissolved organic matter by phytoplankton and its importance to bacteria: patterns across marine and freshwater systems. Limnol Oceanogr 36:1078-1090

Berman T, Viner-Mozzini Y (2001) Abundance and characteristics of polysaccharide and proteinaceous particles in Lake Kinneret. Aquat Microb Ecol 24:255-264

Biddanda B, Benner R (1997) Carbon, nitrogen, and carbohydrate fluxes during the production of particulate and dissolved organic matter by marine phytoplankton. Limnol Oceanogr 42:506-518

Bidle KD, Azam F (2001) Bacterial control of silicon regeneration from diatom detritus: significance of bacterial ectohydrolases and species identity. Limnol Oceanogr 46: 1606-1623

Biersmith A, Benner R (1998) Carbohydrates in phytoplankton and freshly produced dissolved organic matter. Mar Chem 63:131-144

Borch NH, Kirchman DL (1997) Concentration and composition of dissolved combined neutral sugars (polysaccharides) in seawater determined by HPLC-PAD. Mar Chem 57:85-95

Carlson CA, Ducklow HW, Hansell DA, Smith WO (1998) Organic carbon partitioning during spring phytoplankton blooms in the Ross Sea polynya and the Sargasso Sea. Limnol Oceanogr 43:375-386

Cole JJ (1982) Interactions between bacteria and algae in aquatic ecosystems. Annu Rev Ecol Syst 13:291-314

Engel A, Thoms S, Riebesell U, Rochelle-Newall E, Zondervan I (2004) Polysaccharide aggregation as a potential sink of marine dissolved organic carbon. Nature 428: 929-932

Fandino LB, Riemann L, Steward GF, Long RA, Azam F (2001) Variations in bacterial community structure during a dinoflagellate bloom analyzed by DGGE and 16S rDNA sequencing. Aquat Microb Ecol 23:119-130

Ferrier M, Martin JL, Rooney-Varga JN (2002) Stimulation of Alexandrium fundyense growth by bacterial assemblages from the Bay of Fundy. J Appl Microbiol 92:706-716

Gavis J, Ferguson JF (1975) Kinetics of carbon dioxide uptake by phytoplankton at high $\mathrm{pH}$. Limnol Oceanogr 20: 211-221

Green DH, Llewellyn LE, Negri AP, Blackburn SI, Bolch CJS
(2004) Phylogenetic and functional diversity of the cultivable bacterial community associated with the paralytic shellfish poisoning dinoflagellate Gymnodinium catenatum. FEMS Microbiol Ecol 47:345-357

Grossart HP (1999) Interactions between marine bacteria and axenic diatoms (Cylindrotheca fusiformis, Nitzschia laevis, and Thalassiosira weissflogii) incubated under various conditions in the lab. Aquat Microb Ecol 19:1-11

Grossart HP, Schlingloff A, Bernhard M, Simon M, Brinkhoff $\mathrm{T}$ (2004) Antagonistic activity of bacteria isolated from organic aggregates of the German Wadden Sea. FEMS Microb Ecol 47:387-396

Grossart HP, Levold F, Allgaier M, Simon M, Brinkhoff T (2005) Marine diatom species harbour distinct bacterial communities. Environ Microbiol 7:860-873

Grossart HP, Czub G, Simon M (2006a) Specific interactions of planktonic algae and bacteria: consequences for aggregation processes and organic matter cycling in the sea. Environ Microbiol 8:1074-1084

Grossart HP, Kiørboe T, Tang KW, Allgaier M, Yam EM, Ploug $\mathrm{H}$ (2006b) Interactions between marine snow and heterotrophic bacteria: aggregate formation and microbial dynamics. Aquat Microb Ecol 42:19-26

Guerrini F, Mazzotti A, Boni L, Pistocchi R (1998) Bacterialalgal interactions in polysaccharide production. Aquat Microb Ecol 15:247-253

Haines KC, Guillard RRL (1974) Growth of vitamin B12 requiring marine diatoms with vitamin B12 producing marine bacteria. J Phycol 10:245-255

Imai J, Ishida Y, Hata Y (1993) Killing of marine phytoplankton by a gliding bacterium 'Cytophaga sp.', isolated from the coastal Sea of Japan. Mar Biol 116:527-532

Kirchman DL (2002) The ecology of Cytophaga-Flavobacteria in aquatic environments. FEMS Microbiol Ecol 39: 91-100

Lebaron P, Servais P, Troussellier M, Courties C and 6 others (1999) Changes in bacterial community structure in seawater mesocosms differing in their nutrient status. Aquat Microb Ecol 19:255-267

Lindroth P, Mopper K (1979) High performance liquid chromatography determination of subpicomole amounts of amino acids by precolumn fluorescence derivatisation with OPA. Anal Chem 51:1667-1674

Long RA, Azam F (1996) Abundant protein-containing particles in the sea. Aquat Microb Ecol 10:213-221

Long RA, Azam F (2001) Antagonistic interactions among marine pelagic bacteria. Appl Environ Microbiol 67: 4975-4983

Martinez J, Smith DC, Steward GF, Azam F (1996) Variability in ectohydrolytic enzyme activities of pelagic marine bacteria and its significance for substrate processing in the sea. Aquat Microb Ecol 10:223-230

Mayali X, Azam F (2004) Algicidal bacteria in the sea and their impact on algal blooms. J Eukaryot Microbiol 51: 139-144

Meon B, Kirchman DL (2001) Dynamics and molecular composition of dissolved organic material during experimental phytoplankton blooms. Mar Chem 75:185-199

Mopper K, Schultz A, Chevolot L, German, C, Revuelta R, Dawson R (1992) Determination of sugars in unconcentrated saewater and other natural waters by liquid chromatography and pulsed amperometric detection. Environ Sci Technol 26:133-138

Myklestad SM (1974) Production of carbohydrates by marine planktonic diatoms. I. Comparison of nine different species in culture. J Exp Mar Biol Ecol 15:261-274

Myklestad SM (1995) Release of extracellular products by 
phytoplankton with special emphasis on polysaccharides. Sci Total Environ 165:155-164

Obernosterer I, Herndl GJ (1995) Phytoplankton extracellular release and bacterial growth: dependence on the inorganic N:P ratio. Mar Ecol Prog Ser 116:247-257

Passow U (2002a) Transparent exopolymer particles (TEP) in aquatic environments. Prog Oceanogr 55:287-333

Passow U (2002b) Production of transparent exopolymer particles (TEP) by phyto- and bacterioplankton. Mar Ecol Prog Ser 236:1-12

Pinhassi J, Winding A, Binnerup SJ, Zweifel UL, Riemann B, Hagström A (2003) Spatial variability in bacterioplankton community composition at the Skagerrak-Kattegat Front. Mar Ecol Prog Ser 255:1-13

Pinhassi J, Sala MM, Havskum H, Peters F, Guadayol O, Malits A, Marrase CL (2004) Changes in bacterioplankton composition under different phytoplankton regimens. Appl Environ Microbiol 70:6753-6766

Porter KG, Feig YS (1980) The use of DAPI for identifying and counting aquatic microflora. Limnol Oceanogr 25:943-948

Pringsheim EG (1912) Die Kultur von Algen in Agar. Beitr Biol Pflanz 11:305-333

Rhee GY (1972) Competition between an alga and an aquatic bacterium for phosphate. Limnol Oceanogr 17:505-514

Rooney-Varga JN, Giewat MW, Savin MC, Sood S, LeGresley M, Martin JL (2005) Links between phytoplankton and bacterial community dynamics in a coastal marine environment. Microb Ecol 49:163-175

Editorial responsibility: Paul del Giorgio, Montréal, Quebec, Canada
Schäfer H, Abbas B, Witte H, Muyzer G (2002) Genetic diversity of 'satellite' bacteria present in cultures of marine diatoms. FEMS Microbiol Ecol 42:25-35

Søndergaard M, Williams PJleB, Cauwet G, Riemann B, Robinson C, Terzic S, Woodward EMS, Worm J (2000) Net accumulation and flux of dissolved organic carbon and dissolved organic nitrogen in marine plankton communities. Limnol Oceanogr 45:1097-1111

Stoderegger KE, Herndl GJ (1999) Production of exopolymer particles by marine bacterioplankton under contrasting turbulence conditions. Mar Ecol Prog Ser 189:9-16

Thingstad TF, Skjoldal EF, Bohne RA (1993) Phosphorus cycling and algal-bacterial competition in Sandsfjord, western Norway. Mar Ecol Prog Ser 99:239-259

Weiner RM, Melick M, O'Neill K, Quintero E (2000) Hyphomonas adhaerens sp. nov., Hyphomonas johnsonii sp. nov. and Hyphomonas rosenbergii sp. nov., marine budding and prosthecate bacteria. Int J Syst Evol Microbiol 50:459-469

Zhou J, Mopper K, Passow U (1998) The role of surface-active carbohydrates in the formation of transparent exopolymer particles by bubble adsorption of seawater. Limnol Oceanogr 43:1860-1871

Zubkov MV, Fuchs BM, Archer SD, Kiene RP, Amann R, Burkill PH (2001) Linking the composition of bacterioplankton to rapid turnover of dissolved dimethylsulphoniopropionate in an algal bloom in the North Sea. Environ Microbiol 3:304-311

Submitted: June 30, 2006; Accepted: March 6, 2007 Proofs received from author(s): April 21, 2007 